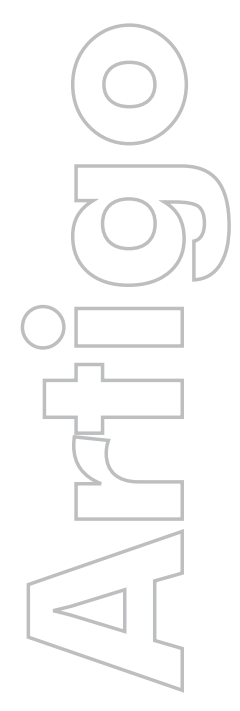

\title{
Mudanças morfológicas e efeitos hidrodinâmicos do processo de urbanização na bacia hidrográfica do
} rio Tamanduateí - Região
Metropolitana de São Paulo

Isabel Cristina Moroz-Caccia Gouveia Unesp

Cleide Rodrigues FFLCH-USP

p. $257-283$

revista

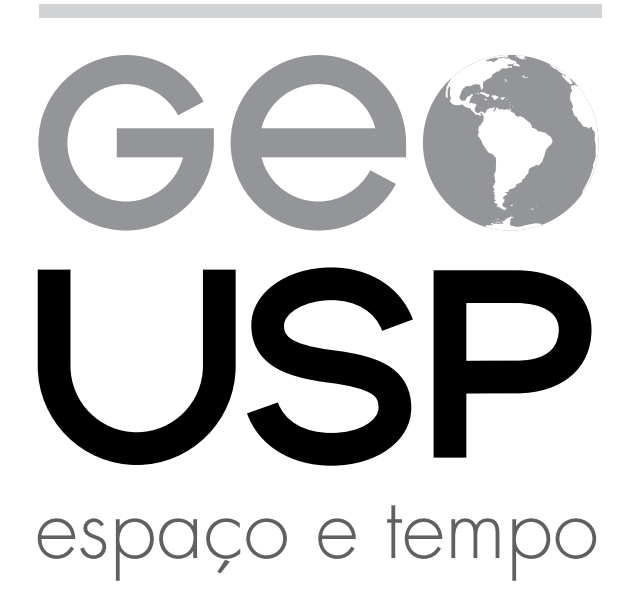

Volume $21 \cdot n^{\circ} 1(2017)$

ISSN 2179-0892
Como citar este artigo:

MOROZ-CACCIA GOUVEIA, I. C.; RODRIGUES, C. Mudanças morfológicas e efeitos hidrodinâmicos do processo de urbanização na bacia hidrográfica do rio Tamanduateí Região Metropolitana de São Paulo. Geousp - Espaço e Tempo (Online), v. 21, n. 1, p. 257-283, abril. 2017. ISSN 2179-0892.

Disponível em: < http://www.revistas.usp.br/geousp/ article/view/105342>. doi: 10.11606/issn.2179-0892. geousp.2017.105342.

\section{(c) (1) $(9$}

Este artigo está licenciado sob a Creative Commons Attribution 4.0 License. 


\section{Mudanças morfológicas e efeitos hidrodinâmicos do processo de urbanização na bacia hidrográfica do rio Tamanduateí - RMSP}

\section{Resumo}

Apoiado na geomorfologia antropogênica e histórica, este artigo apresenta metodologia aplicada à bacia hidrográfica do rio Tamanduateí para analisar qualitativa e quantitativamente as mudanças decorrentes da urbanização em sistemas físicos a partir da cartografia geomorfológica. A premissa principal dessa abordagem é considerar as ações humanas na paisagem como ações de natureza geomorfológica cujos efeitos podem ser medidos por indicadores e parâmetros. Entre outras análises, a identificação de características originais ou pré-urbanas e de mudanças antropogênicas permitiu estimar a perda da capacidade de armazenamento de água devido à supressão de planícies fluviais e mudanças no balanço hidrodinâmico nas vertentes da bacia hidrográfica.

Palavras-chave: Urbanização. Mudanças morfológicas. Balanço hidrodinâmico. Cartografia geomorfológica. Geomorfologia antropogênica e histórica.

\section{Morphological changes and hydrodynamic effects of the urbanization process of river Tamanduateí watershed - Metropolitan area of São Paulo}

\footnotetext{
Abstract

Relying on Anthropogenic and Historical Geomorphology, this paper presents methodology applied to the River Tamanduateí watershed for qualitative and quantitative analysis of changes resulting from the urbanization process in physical systems, from the geomorphological cartography. The approach has as its main premise consider the human actions into the landscape as geomorphological nature of actions whose effects can be measured using
} 
indicators and benchmarks. Among other analysis, the identification of the original or pre-urban characteristics and anthropogenic changes allowed us to estimate the loss of the water storage capacity due to the suppression of river plains and changes in hydrodynamic balance in the areas of hydrographic basin.

Keywords: Urbanization. Morphological changes. Hydrodynamic balance. Geomorphologic cartography. Anthropogenic and historical geomorphology.

\section{Introdução}

A mancha urbana da cidade de São Paulo, desde sua fundação em 1554 até meados do século XIX, restringiu-se a uma parte do interflúvio ribeirão Anhangabaúrio Tamanduateí. Somente a partir da segunda metade daquele século é que começou a expandir-se, para então transformar-se paulatinamente em uma grande metrópole. Acompanhando o ritmo da expansão territorial, diversos problemas de ordem ambiental foram desencadeados ou amplificados. De forma geral, é possível afirmar que estes resultaram de uma sobreposição histórico-geográfica de intervenções que não consideraram as características ambientais, o que explicita a precária utilização de instrumentos de planejamento e gestão territorial que ora optaram por ações equivocadas, ora foram sobrepujados por interesses de setores sociais específicos. Entre eles podem ser citados: inundações e alagamentos, processos erosivos agressivos, assoreamentos e colmatagens, e movimentos gravitacionais de massa. Tratam-se de processos geomorfológicos que se configuram em problemas ambientais dentro de áreas urbanas, principalmente em decorrência do aumento de sua frequência e de sua magnitude.

Diante desse quadro, o meio físico destaca-se como um dos elementos da paisagem que mais interage diretamente com o ambiente construído, tornando-se relevante para a compreensão de grande parte dos problemas urbanos.

Com o intuito de identificar as características pré-urbanas dos sistemas hidrogeomorfológicos, as mudanças impostas pela ocupação urbana e as respostas ambientais resultantes na Região Metropolitana de São Paulo (RMSP), elegeu-se como área de estudo, a bacia hidrográfica do rio Tamanduateí (BHRT) (Figura 1). A escolha da área justifica-se tanto em relação à representatividade das unidades morfológicas da RMSP, quanto em termos de diversidade e sobreposições de mudanças antrópicas históricas, uma vez que foi onde se iniciou o processo de urbanização de São Paulo. 


\section{Figura 1}

\section{Localização da área de estudo}

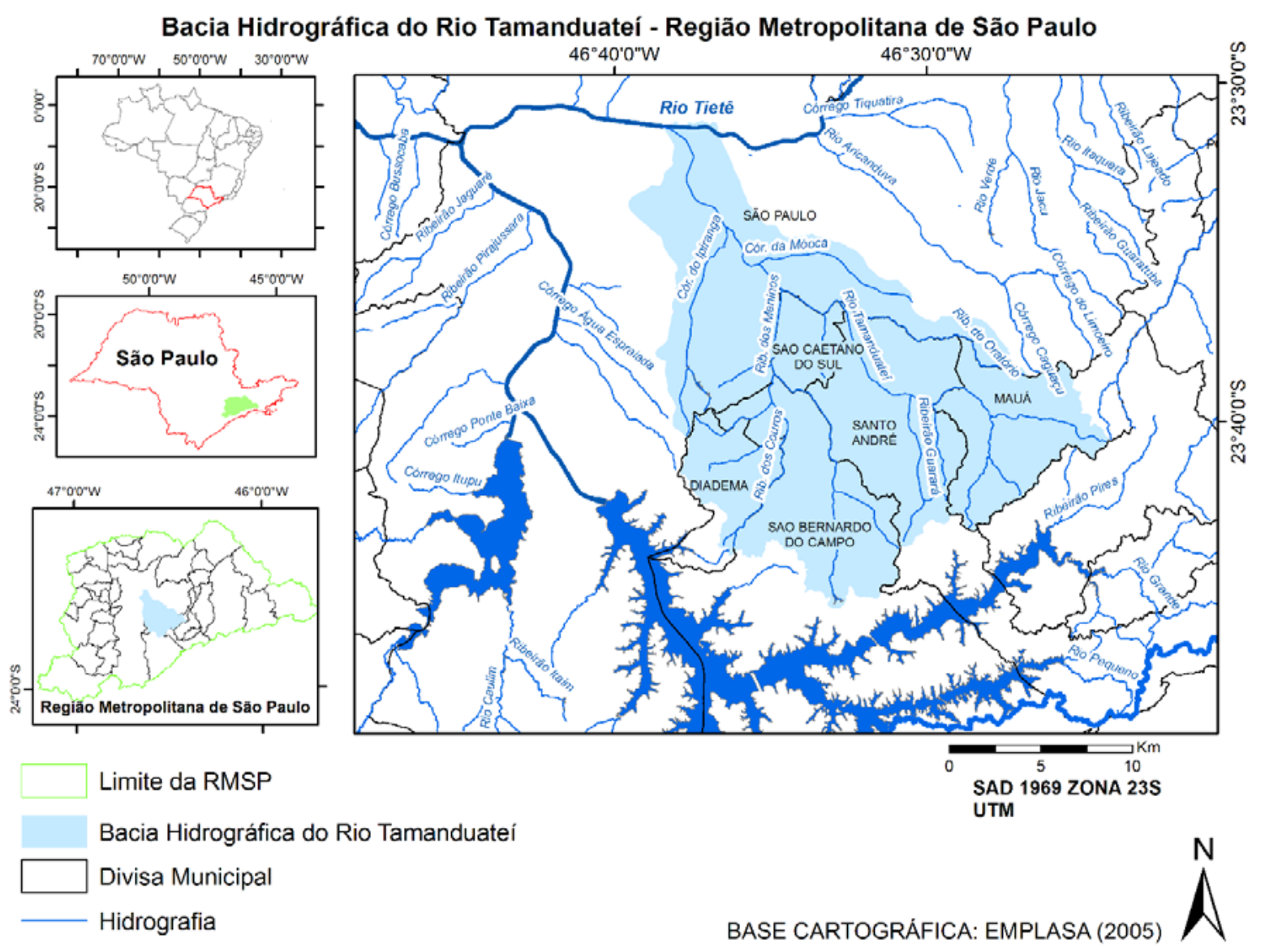

organização: As autoras.

O rio Tamanduateí nasce no município de Mauá e deságua no rio Tietê, passando pelos municípios de Santo André, São Caetano do Sul e São Paulo. Sua bacia hidrográfica, que ocupa uma área de $323 \mathrm{~km}^{2}$ e corresponde a uma sub-bacia do Alto Tietê, abrange ainda trechos dos municípios de São Bernardo do Campo e Diadema.

\section{Materiais e métodos}

A pesquisa foi conduzida de acordo com metodologia denominada geomorfologia antropogênica e histórica, delineada inicialmente em Lima (1990) e desenvolvida por Rodrigues (1997, 2004, 2005, 2006, 2008, 2010) e também em estudos realizados por Moroz-Caccia Gouveia (2010), Berges (2013) e Luz (2014). Apoia-se em referências e princípios selecionados de estudos geomorfológicos voltados à análise dos efeitos da ação antrópica no meio físico e na paisagem (Douglas, 1975, 1983; Goudie, 1984, 1994; Nir, 1983; Gupta, 1993), em estudos voltados às modificações dos ambientes físicos pela urbanização na RMSP (Ab'Sáber, 1953, 1957, 1959, 1961, 1978, 1999, 2003, 2004a e 2004b; Seabra, 1987), na valorização de documentos históricos e na produção 
cartográfica evolutiva para auxiliar na seleção e na efetiva comparação entre indicadores e parâmetros de interesse para os processos geomorfológicos.

A cartografia evolutiva possibilita análises retrospectivas hidrogeomorfológicas, voltadas às condições originais de sistemas e subsistemas físicos - suas condições préurbanas, e às condições geomorfologicamente representativas de diversos momentos do processo histórico de produção do espaço urbano. Visa reconhecer e dimensionar diversos graus de derivação antrópica, propiciando uma variedade de raciocínios valorativos. Utilizando-se indicadores morfológicos, de materiais superficiais e de processos hidrodinâmicos é possível, por exemplo, avaliar o grau de artificialidade desses sistemas, assim como os atores sociais responsáveis pelas mudanças identificadas (Rodrigues, 2008).

A partir dessa perspectiva, a pesquisa consistiu no resgate cartográfico da configuração geomorfológica pré-urbana da área estudada e na identificação das mudanças morfológicas impostas pela ocupação urbana, com o objetivo de estimar a influência das intervenções antrópicas nos balanços, frequência e magnitude de processos hidrogeomorfológicos.

Para alcançar esse objetivo foram elaborados os seguintes produtos cartográficos:

- Mapa da geomorfologia pré-urbana (morfologia original): considerou-se morfologia original aquela cujos atributos morfológicos e morfométricos (extensão, declividades, rupturas e mudanças de declives, entre outros) não sofreram alterações significativas por intervenção antrópica direta ou indireta. (Rodrigues, 2005). A elaboração desse produto cartográfico, orientada por princípios e métodos já consagrados na cartografia geomorfológica, foi efetuada por meio de interpretações de fotografias aéreas de 1952 e 1962, cartas topográficas e documentação cartográfica (Quadro 1) e iconográfica dos séculos XIX e XX (Figura 2);

- Mapa da morfologia antropogênica: foi produzido a partir das cartas de uso e ocupação do solo da RMSP e da bacia do Alto Tietê (Emplasa, 2005). As classes de uso e ocupação do solo foram agrupadas de acordo com interpretação geomorfológica dos efeitos hidrogeomorfológicos potencialmente resultantes (Quadro 2); e,

- Mapa das modificações nos canais fluviais da BHRT elaborado com base na cartografia antiga (século XIX e início XX), fotografias aéreas e cartas topográficas (Quadro 1).

\section{Quadro 1}

Cartas topográficas e documentação cartográfica utilizadas para elaborar os mapas da geomorfologia pré-urbana (morfologia original) e o das modificações nos canais fluviais

\begin{tabular}{|c|c|}
\hline \multicolumn{1}{|c|}{ materiais cartográficos } & \multicolumn{1}{c|}{ referências } \\
\hline $\begin{array}{l}\text { carta geomorfológica do Planalto Paulis- } \\
\text { tano e vizinhanças (1953), escala aproxi- } \\
\text { mada 1:200.000 }\end{array}$ & $\begin{array}{l}\text { ALMEIDA, F. F. M. In: AZEVEDO, A. A cidade de São Paulo. v. 1. A } \\
\text { região de São Paulo. São Paulo: AGB-SP, 1953. }\end{array}$ \\
\hline
\end{tabular}




\begin{tabular}{|c|c|}
\hline materiais cartográficos & referências \\
\hline $\begin{array}{l}\text { mapa geomorfológico esquemático do } \\
\text { sítio urbano de São Paulo (1957), } \\
\text { escala aproximada 1:75.0000 }\end{array}$ & $\begin{array}{l}\text { AB'SÁBER, A. N. Geomorfologia do sítio urbano de São Paulo. Tese } \\
\text { (Doutorado em Geografia Física) - Faculdade de Filosofia, Letras e } \\
\text { Ciências Humanas, Universidade de São Paulo. Geografia, São Paulo, } \\
\text { v. } 12 \text {, boletim n. } 219,1957 .\end{array}$ \\
\hline $\begin{array}{l}\text { planta da imperial cidade de São Paulo } \\
\text { (1810 - reedição de } 1941 \text {, com acrésci- } \\
\text { mos), escala aproximada 1:10.000 }\end{array}$ & $\begin{array}{l}\text { COSTA, R. J. F. In: Comissão do IV Centenário de cidade de São Paulo. } \\
\text { São Paulo antigo: plantas da cidade. São Paulo: Melhoramentos, } 1954 .\end{array}$ \\
\hline $\begin{array}{l}\text { planta da cidade de São Paulo 1841, } \\
\text { escala aproximada 1:5.000 }\end{array}$ & $\begin{array}{l}\text { BRESSER, C. A. In: Comissão do IV Centenário de cidade de São } \\
\text { Paulo. São Paulo antigo: plantas da cidade. São Paulo: Melhoramentos, } \\
\text { 1954. }\end{array}$ \\
\hline $\begin{array}{l}\text { mappa da cidade de São Paulo e seus su- } \\
\text { búrbios s/d (c. 1847) } \\
\text { escala aproximada 1:5.000 }\end{array}$ & $\begin{array}{l}\text { BRESSER, C. A. In: Comissão do IV Centenário de cidade de São } \\
\text { Paulo. São Paulo antigo: plantas da cidade. São Paulo: Melhoramentos, } \\
\text { 1954. }\end{array}$ \\
\hline $\begin{array}{l}\text { mappa da imperial cidade de São Paulo } \\
\text { (1855), escala aproximada 1:10.000 }\end{array}$ & $\begin{array}{l}\text { RATH, C. In: Comissão do IV Centenário de cidade de São Paulo. } \\
\text { São Paulo antigo: plantas da cidade. São Paulo: Melhoramentos, } 1954 .\end{array}$ \\
\hline $\begin{array}{l}\text { planta da cidade de São Paulo (1868), } \\
\text { escala aproximada 1:10.000 }\end{array}$ & $\begin{array}{l}\text { RATH, C. In: Comissão do IV Centenário de cidade de São Paulo. } \\
\text { São Paulo antigo: plantas da cidade. São Paulo: Melhoramentos, } 1954 .\end{array}$ \\
\hline $\begin{array}{l}\text { mapa da capital da Província de São } \\
\text { Paulo (1877), escala aproximada 1:3.500 }\end{array}$ & $\begin{array}{l}\text { ALBUQUERQUE, F; MARTIN, J. In: Comissão do IV Centenário de } \\
\text { cidade de São Paulo. São Paulo antigo: plantas da cidade. São Paulo: } \\
\text { Melhoramentos, } 1954 \text {. }\end{array}$ \\
\hline $\begin{array}{l}\text { planta da capital do estado de São Paulo e } \\
\text { seus arredores (1890), escala aproximada } \\
1: 6.000\end{array}$ & $\begin{array}{l}\text { MARTIN, J. In: Comissão do IV Centenário de cidade de São Paulo. } \\
\text { São Paulo antigo: plantas da cidade. São Paulo: Melhoramentos, } 1954 .\end{array}$ \\
\hline $\begin{array}{l}\text { planta da cidade de São Paulo (1895), } \\
\text { escala 1:10.000 }\end{array}$ & $\begin{array}{l}\text { BONVICINI, H. (Ed.). In: Comissão do IV Centenário de cidade de } \\
\text { São Paulo. São Paulo antigo: plantas da cidade. São Paulo: Melhora- } \\
\text { mentos, } 1954 \text {. }\end{array}$ \\
\hline $\begin{array}{l}\text { planta geral da capital de São Paulo } \\
\text { (1897), escala aproximada } 1: 20.000\end{array}$ & $\begin{array}{l}\text { CARDIM, G. In: Comissão do IV Centenário de cidade de São Paulo. } \\
\text { São Paulo antigo: plantas da cidade. São Paulo: Melhoramentos, } 1954 .\end{array}$ \\
\hline $\begin{array}{l}\text { planta geral da cidade de São Paulo } \\
\text { (1905), escala 1:20.000 }\end{array}$ & $\begin{array}{l}\text { COCOCI, A. M.; COSTA, L. F. L. In: Secretaria do Estado de Eco- } \\
\text { nomia e Planejamento/Instituto Geográfico e Cartográfico (IGC). } \\
\text { Disponível em: http://sempla.prefeitura.sp.gov.br. Acesso } 15 \text { mar. } 2017 .\end{array}$ \\
\hline $\begin{array}{l}\text { planta geral da cidade de São Paulo } \\
\text { (1914), escala 1:20.000 }\end{array}$ & $\begin{array}{l}\text { COMISSÃO GEOGRÁFICA E GEOLÓGICA. In: Secretaria do Es- } \\
\text { tado de Economia e Planejamento/Instituto Geográfico e Cartográfi- } \\
\text { co (IGC). Disponível em: http://sempla.prefeitura.sp.gov.br. Acesso } 15 \\
\text { mar. } 2017 \text {. }\end{array}$ \\
\hline $\begin{array}{l}\text { mappa topographico do município de } \\
\text { São Paulo, 1930, escala 1:30.000, folha } \\
\text { IV }\end{array}$ & Sara Brasil S/A e Prefeitura do Município de São Paulo, 1930. \\
\hline $\begin{array}{l}\text { mappa topographico do município de } \\
\text { São Paulo, 1930, escala 1:5.000, folhas } \\
37,50,51,52,65 \text { e } 66 \text {. }\end{array}$ & Sara Brasil S/A e Prefeitura do Município de São Paulo, 1930. \\
\hline $\begin{array}{l}\text { planta da cidade de São Paulo e mu- } \\
\text { nicípios circunvizinhos (1943), escala } \\
\text { 1:50.000. }\end{array}$ & $\begin{array}{l}\text { The São Paulo Tramway Light E Power Co. LTD. In: Secretaria do } \\
\text { Estado de Economia e Planejamento/Instituto Geográfico e Cartográ- } \\
\text { fico (IGC). Disponível em: http://sempla.prefeitura.sp.gov.br. Acesso } 15 \\
\text { mar. } 2017 \text {. }\end{array}$ \\
\hline $\begin{array}{l}\text { fotografias aéreas } 1952 \\
\text { Escala } 1: 20.000\end{array}$ & $\begin{array}{l}\text { Serviços Aerofotogramétricos Cruzeiro do Sul } \\
\text { Faixa } 5 \text { (094-091); Faixa } 4(070 \text { - 076); Faixa } 3 \text { (O53-048); Faixa } 2 \\
(034-042) \text { e Faixa } 1 \text { (013-003) }\end{array}$ \\
\hline $\begin{array}{l}\text { fotografias aéreas } 1962 \\
1: 25.000\end{array}$ & $\begin{array}{l}\text { Instituto Agronômico de Campinas - Aerofoto Natividade S/A } \\
\text { Região } 7 \text { T 4015-4007 }\end{array}$ \\
\hline
\end{tabular}




\section{Quadro 2}

\section{Descrição das morfologias semipreservadas e antropogênicas}

\begin{tabular}{|c|c|c|}
\hline \multicolumn{2}{|c|}{ categorias } & descrição \\
\hline \multicolumn{2}{|c|}{ morfologia semipreservada } & $\begin{array}{l}\text { corresponde a áreas predominantemente dotadas de cobertura ve- } \\
\text { getal (matas, capoeiras, campos, vegetação de várzeas, refloresta- } \\
\text { mentos, áreas verdes urbanas); e, cursos d'água com características } \\
\text { originais ou semipreservadas }\end{array}$ \\
\hline \multirow{3}{*}{$\begin{array}{l}\text { morfologias } \\
\text { antropogênicas } \\
\text { decorrentes da } \\
\text { ocupação urbana }\end{array}$} & $\begin{array}{l}\text { estágio inicial de } \\
\text { ocupação urbana }\end{array}$ & loteamentos desocupados ou em processo de ocupação \\
\hline & $\begin{array}{l}\text { estágio } \\
\text { intermediário de } \\
\text { ocupação urbana }\end{array}$ & $\begin{array}{l}\text { áreas urbanas altamente impermeabilizadas, geralmente sem infraes- } \\
\text { truturas }\end{array}$ \\
\hline & $\begin{array}{l}\text { estágio final de } \\
\text { ocupação urbana }\end{array}$ & $\begin{array}{l}\text { áreas urbanas consolidadas, altamente impermeabilizadas, dotadas de } \\
\text { infraestruturas }\end{array}$ \\
\hline \multicolumn{2}{|c|}{ outras morfologias antropogênicas } & $\begin{array}{l}\text { correspondem a morfologias antropogênicas que não se relacionam } \\
\text { diretamente com estágios de urbanização como: solo exposto/movi- } \\
\text { mento de terra e mineração }\end{array}$ \\
\hline
\end{tabular}

\section{Figura 2}

\section{Exemplos de documentos cartográficos e iconográficos utilizados na pesquisa}

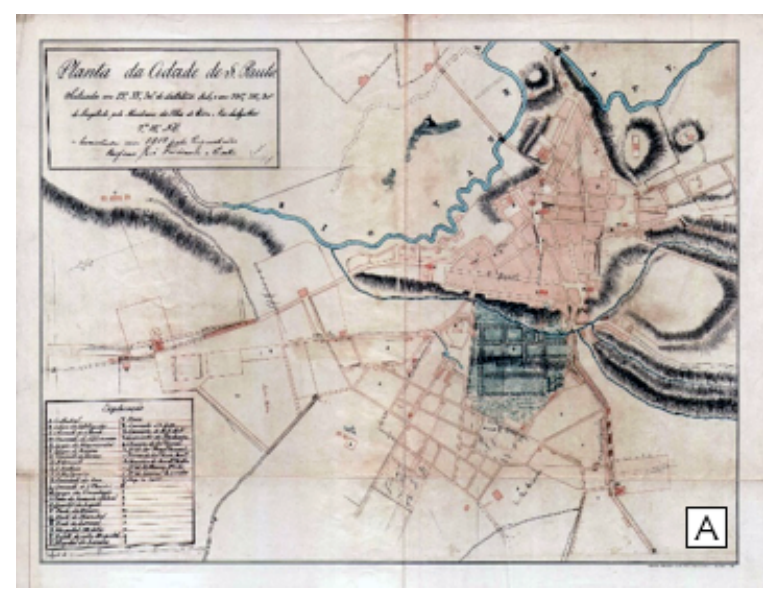

(A) Planta de São Paulo, de 1810, de Rufino e Costa. fonte: São Paulo (2008).

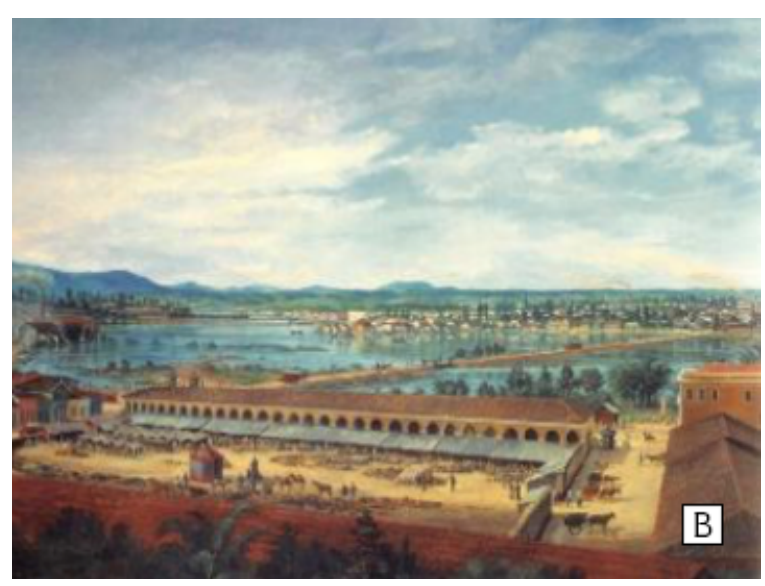

(B) Inundação da várzea do Carmo (detalhe do panorama), óleo sobre tela de Benedito Calixto, tomada da colina central em direção nordeste.

fonte: Lago (1998).

Além das avaliações de caráter qualitativo acerca das mudanças nas formas, materiais e processos em função da ocupação urbana, a correlação entre os produtos cartográficos permitiu avaliações espaciais quantitativas a partir de indicadores e parâmetros selecionados, ${ }^{1}$ tais como:

1 Rodrigues (2010) apresenta um amplo quadro de indicadores e instrumentais para avaliação de impactos e mudanças em sistemas hidrogeomorfológicos urbanizados. 
- Indicador materiais superficiais e cobertura vegetal para as planícies de inundação: Correlação entre áreas ocupadas originalmente pelas planícies de inundação (Mapa de morfologia pré-urbana, corroborado pelos dados de Ab'Sáber (1957)) e áreas que atualmente ainda têm morfologia semipreservada, embora apresentem-se impermeabilizadas ou com solos remanejados (Mapa de morfologia antropogênica);

- Indicador morfologia (parâmetros comprimento e padrão) para os canais fluviais: comprimento e padrão dos canais fluviais originais e atuais (Mapa das modificações nos canais fluviais da bacia hidrográfica do rio Tamanduateí);

- Indicador processos hidromorfológicos para as planícies de inundação: capacidade de armazenamento das áreas originalmente ocupadas por planícies de inundação, das áreas atuais com essa morfologia semipreservada e dos reservatórios de detenção (piscinões) instalados na BHRT. Considerou-se, para efeito dos cálculos, que a capacidade natural de armazenamento das planícies de inundação é de $1 \mathrm{~m}^{3} / \mathrm{m}^{2}$ de superfície; ${ }^{2}$ e,

- Indicador hidromorfológico nos conjuntos de vertentes: a estimativa de mudanças no comportamento hidrogeomorfológico da BHRT, baseou-se no fluxograma (Figura 3), organizado de acordo com os estudos de Savigear (1965), Troeh (1965), Dylik (1968), Ruhe $(1975)$ e Ross $(1990,2004)$ acerca das relações processuais em vertentes.

\section{Figura 3}

\section{Fluxograma do comportamento hidrodinâmico das morfologias originais e morfologias antropogênicas}
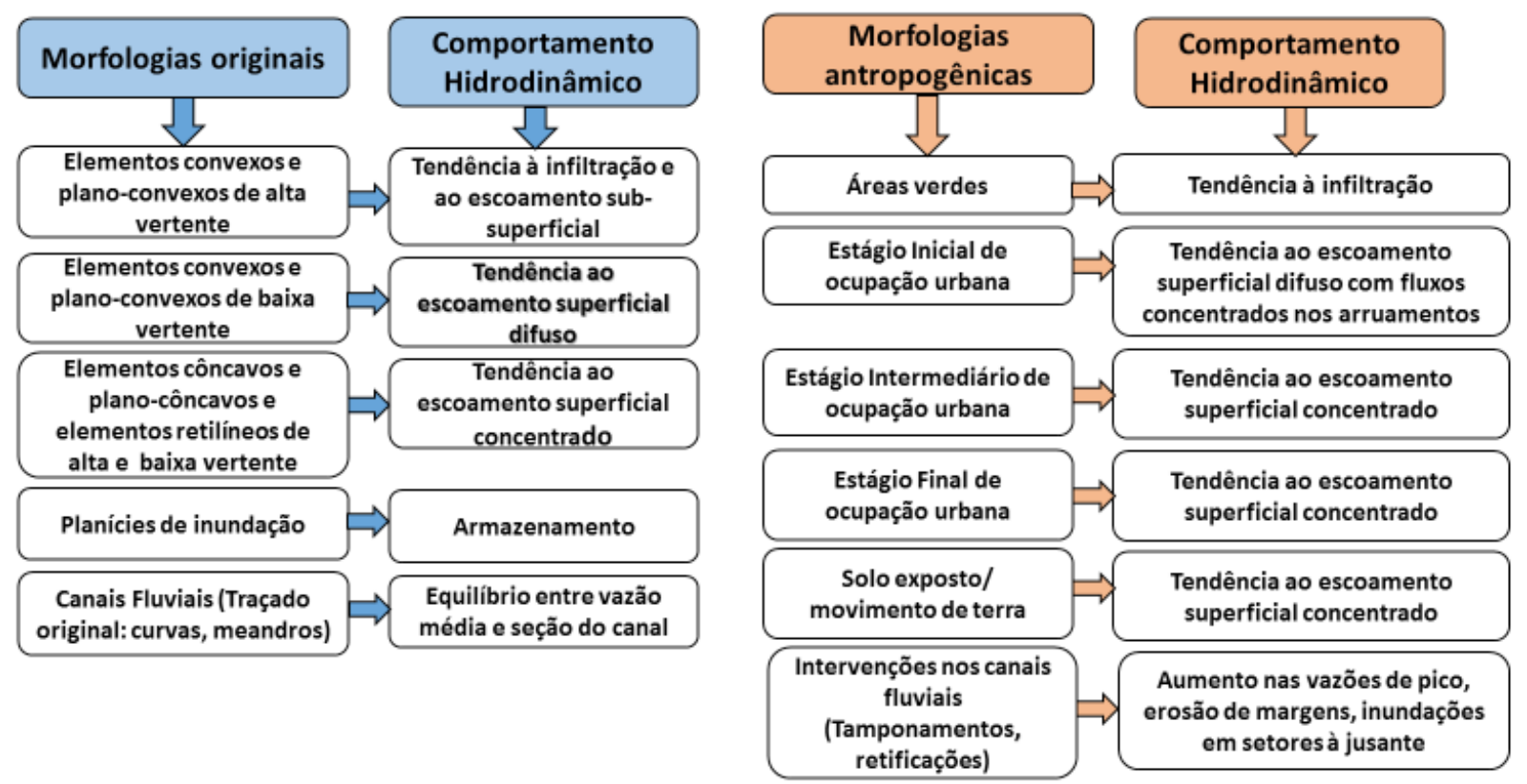

organização: As autoras.

2 Os cálculos foram orientados pelas proposições do Scottish Executive Environment Group Research (2005), que definem a capacidade de estocagem (the flood storage capacity) como parte da função de atenuação de fluxos extremos das planícies fluviais (Rodrigues et al., 2014; Rodrigues, 2015). 


\section{RESULTADOS E DISCUSSÕES}

\section{Geomorfologia pré-urbana}

Como se observa na Figura 4, a BHRT drena em sua porção superior os terrenos cristalinos correspondentes à unidade morfoescultural Planalto Paulistano/Alto Tietê (Planalto Atlântico), inserida na unidade morfoestrutural do Cinturão Orogênico do Atlântico. Essa porção, apresenta modelado caracterizado por morros baixos a médios, com topos convexos e dissecação média. A litologia é basicamente constituída por migmatitos, granitos, micaxistos e gnaisses (Ross; Moroz, 1997). As altimetrias predominantes situam-se entre 800 a $980 \mathrm{~m}$, e as declividades entre 20 a $30 \%$, embora algumas áreas possam apresentar declividades acima de 60\%. A drenagem, de padrão dendrítico, corresponde às bacias de até $4{ }^{\circ}$ ordem dos principais cursos d'água formadores da BHRT, tais como o ribeirão dos Couros, ribeirão dos Meninos, rio Guarará e ribeirão Serraria.

\section{Figura 4}

Mapa da geomorfologia pré-urbana da bacia hidrográfica do rio Tamanduateí

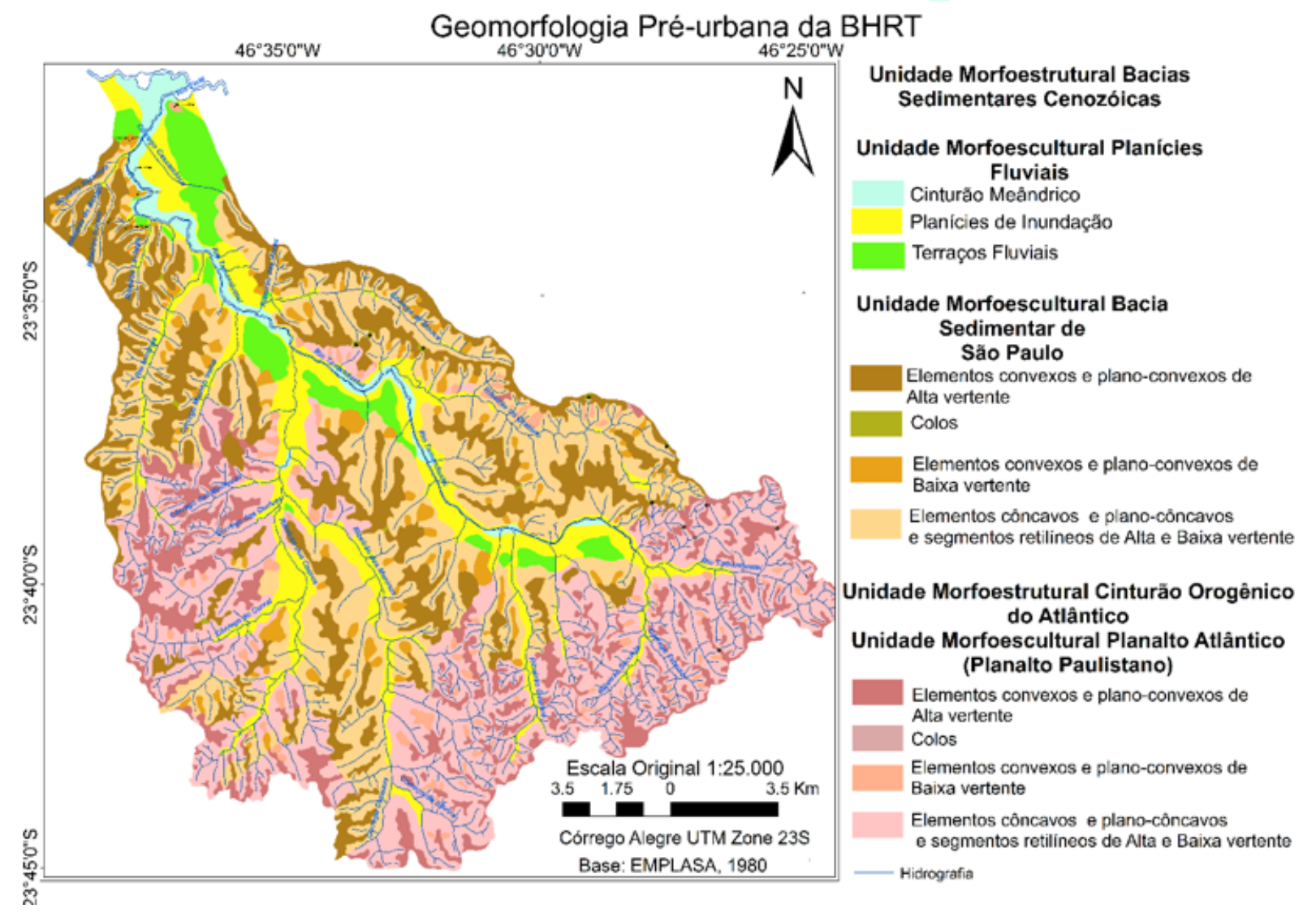

O restante da bacia hidrográfica localiza-se na unidade morfoescultural Planalto de São Paulo, que corresponde à Bacia Sedimentar Terciária de São Paulo. Segundo Ross e Moroz (1997), nessa unidade predominam formas de relevo cujos modelados 
constituem-se por colinas e patamares aplanados. As altimetrias predominantes situamse entre 700 a 800 metros e as declividades dominantes variam entre 10 a $30 \%$. A litologia constitui-se basicamente por argilas, areias e lentes de conglomerados. A drenagem, de maneira geral, apresenta padrão paralelo. Apenas alguns pequenos cursos d'água (de $1^{\text {a }}$ e 2a ordem) apresentam padrão dendrítico.

Alojadas nas duas unidades descritas acima, encontram-se as planícies fluviais do rio Tamanduateí e afluentes. Associadas aos terrenos cristalinos observavam-se planícies fluviais estreitas e alongadas, que se estendiam desde os trechos iniciais dos principais cursos d'água, em altitudes situadas em torno de $800 \mathrm{~m}$. O rio Tamanduateí, ao percorrer apenas uma pequena área desse compartimento de relevo, contava também com a presença de planícies e terraços fluviais em seu trecho inicial, embora restritos à sua margem esquerda. Ao atingir a bacia sedimentar, a planície do rio Tamanduateí imediatamente se alargava, principalmente na margem esquerda, chegando a perfazer até $400 \mathrm{~m}$ de largura, e passava também a apresentar cinturão meândrico. Além da planície fluvial do rio Tamanduateí, que se estendia por mais de $16 \mathrm{~km}$, merecem destaque ainda as planícies fluviais do Ribeirão dos Meninos, que apresentava pequeno trecho de cinturão meândrico, e Ribeirão dos Couros, além das planícies menos expressivas do rio Ipiranga, córrego da Moóca, córrego do Oratório e ribeirão Guarará.

As morfologias originais ou pré-urbanas identificadas no Mapa da geomorfologia pré-urbana da BHRT (Figura 4), apresentavam a seguinte distribuição (Figura 5):

\section{Figura 5}

\section{Distribuição das morfologias pré-urbanas na BHRT}

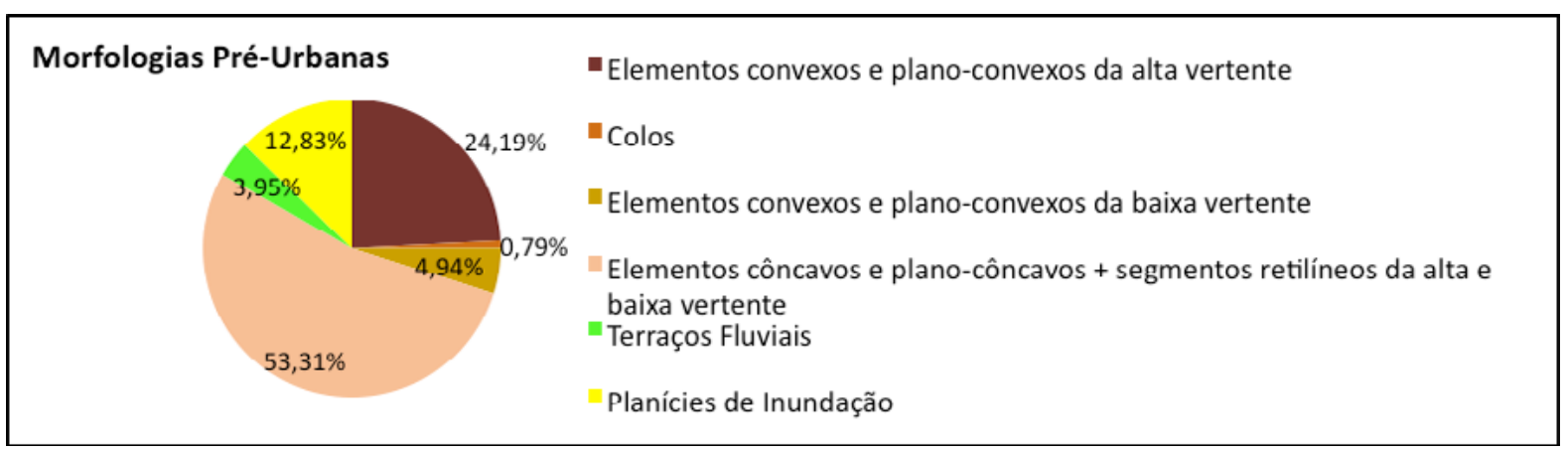

Apoiando-se nos estudos de Savigear (1965), Troeh (1965), Dylik (1968), Ruhe (1975) e Ross $(1990 ; 2004)$, apresentam-se a seguir as tendências de comportamentos hidrodinâmicos associadas às morfologias identificadas:

- Elementos convexos e plano-convexos de alta vertente: os elementos de vertente dotados de geometria convexa apresentam tendência a dispersar os fluxos hídricos. No entanto, na região estudada, quando situados no terço superior de uma vertente, por apresentarem declividades moderadas, a dispersão de fluxos é atenuada. Assim, em condições originais, com cobertura florestal, prevaleceriam a infiltração e o escoamento subsuperficial. Haveria, portanto, um balanço equilibrado entre escoamento superficial e 
infiltração ou, entre o componente paralelo e o componente perpendicular. Desse modo, em função da importância deste último, seriam aí também importantes os processos de erosão química, promovendo o espessamento do manto de alteração, o que poderia favorecer, naturalmente, a ocorrência de movimentos de massa como rastejamentos, sobretudo nos terrenos cristalinos;

- Colos: elementos de vertente que apresentam tendência à concentração de água por escoamento superficial e subsuperficial e concentração de detritos finos, transportados por escoamento superficial. Podem apresentar espessamento do manto de intemperismo. São áreas sujeitas, naturalmente, à erosão regressiva de cabeceiras;

- Elementos convexos e plano-convexos de baixa vertente: apresentariam, em condições originais, tendência à dispersão de água por escoamento superficial difuso e, portanto, à erosão laminar;

- Elementos côncavos e plano-côncavos e segmentos retilíneos de alta e baixa vertente: os elementos côncavos são mais frequentes nas altas e médias vertentes correspondendo, geralmente, às cabeceiras de drenagens, que se configuram em nichos de nascentes em forma de anfiteatros. Essa morfologia, em condições originais, apresentaria tendência à convergência de fluxos hídricos em superfície e subsuperfície, podendo gerar escoamento superficial concentrado, sobretudo, nas partes inferiores da vertente. Nos segmentos retilíneos, em condições originais ou pré-urbanas, prevaleceriam processos de escoamento subsuperficial e escoamento superficial difuso nas altas e médias vertentes, podendo também apresentar escoamento superficial concentrado em partes das baixas vertentes;

- Terraços Fluviais: a presença de depósitos turfosos holocênicos, observados por Ab'Sáber (1957) recobrindo terraços bem como trechos da planície de inundação e sopés das colinas, na área de estudo evidenciam problemas de má drenagem e saturação dos solos nessa morfologia, em suas condições originais. Essas características hidrodinâmicas, associadas às características do material superficial original, constituído por sedimentos inconsolidados e material turfoso, podem implicar em problemas de instabilidade, dificultando a instalação e manutenção de edificações e de infraestrutura superficial (obras viárias, por exemplo) e subterrânea (túneis, dutos etc.); e,

- Planícies de inundação: por constituírem-se em leito maior dos sistemas fluviais, essa morfologia caracteriza-se pela ocorrência de inundações. Durante os períodos chuvosos, quando as vazões superam a capacidade de escoamento do canal fluvial (leito menor), ocorre o extravasamento das margens plenas e as águas espraiam-se na planície de inundação. Portanto, as planícies de inundação desempenham a função de armazenamento temporário de águas, aumentando o tempo de concentração de água na bacia hidrográfica e reduzindo as vazões de pico.

\section{Morfologia antropogênica}

As mudanças antropogênicas decorrentes da ocupação urbana, quer sejam pela modificação das formas ou substituição de materiais superficiais, interferem no ciclo 
hidrológico e, consequentemente, nos processos hidromorfodinâmicos, sobretudo numa bacia hidrográfica em meio tropical úmido, onde a dinâmica de circulação da água (na superfície, subsuperfície e atmosfera) desempenha papel potencializador.

A retirada da cobertura vegetal, passo inicial para o assentamento urbano, restringe (e, em alguns casos, elimina) a participação da evapotranspiração no ciclo hidrológico, e ao diminuir a capacidade de infiltração da água no solo, reduz a circulação de água em subsuperfície e o abastecimento do lençol freático, acentuando diferenças sazonais no regime hídrico. Ou seja, nos períodos de estiagens, a vazões são drasticamente reduzidas. À medida que a ocupação urbana numa bacia hidrográfica se intensifica e se consolida, a participação do escoamento superficial na hidrodinâmica se torna ainda mais significativa. A impermeabilização das superfícies (edificações, pavimentação de lotes e vias de circulação), diminui drasticamente a infiltração de água no solo e, por outro lado, acelera a velocidade dos fluxos de escoamento superficial, reduzindo o tempo de concentração de água na bacia e antecipando vazão de pico. (Rodrigues; Moroz-Caccia Gouveia, 2013).

Tucci (2000), analisando pequenas bacias, chegou aos seguintes indicadores: (a) um habitante produz cerca de $49 \mathrm{~m}^{2}$ de área impermeável numa bacia; (b) apenas o arruamento produz aumento do volume e do coeficiente de escoamento da ordem de 260\%; e, (c) para cada 13\% de ocupação com área impermeável no lote, ocorre aumento de $115 \%$ no coeficiente de escoamento. $O$ autor adverte que tais números são médios, mas permitem analisar o impacto quantitativo das ações da urbanização numa bacia hidrográfica.

Com relação aos processos morfodinâmicos, o solo, desprovido de proteção, torna-se vulnerável ao impacto das chuvas, e os processos erosivos se deflagram. Por sua vez, todo o material erodido é rapidamente transportado pelos fluxos pluviais e, ao atingir os cursos d'água, ali se depositam, reduzindo a capacidade de vazão dos mesmos e consequentemente, aumentando a ocorrência de inundações. À medida que os processos naturais de infiltração e escoamento superficial são modificados e os cursos d'água são assoreados, eventos pluviométricos de menor intensidade e duração vão se tornando suficientes para acarretarem inundações. Assim, a frequência e magnitude de inundações aumentam.

Tucci e Collischonn (2000), afirmam que as taxas de erosão variam de acordo com a fase de urbanização. À medida que a ocupação urbana em uma bacia hidrográfica vai se consolidando, a tendência é que as taxas de produção de sedimentos diminuam. Desse modo, o que se verifica é um incremento na taxa de produção de sedimentos nas fases iniciais da urbanização, atingindo seu máximo no período de perturbação ativa para, em seguida, regredirem.

No caso da BHRT, as taxas de produção de sedimentos ainda são significativas. Embora grande parte da bacia já esteja urbanizada (cerca de $92 \%$ ), a ocupação urbana em estágio inicial, mais restrita aos trechos superiores da bacia, muito contribui na produção de sedimentos pois corresponde aos terrenos cristalinos, cujos solos são 
bastante suscetíveis aos processos erosivos. Também por configurarem-se em terrenos de declividades acentuadas, sofrem cortes e aterros, para a instalação de moradias. As ações de terraplenagens implicam na remoção das camadas superiores dos solos - mais estruturadas e, além de exporem os materiais mais susceptíveis (horizonte $\mathrm{C}$ ), implicam em mudanças na geometria das vertentes, alterando o equilibrio, ocasionando inclusive movimentos de massa.

As áreas cartografadas no Mapa da morfologia antropogênica (Figura 6) como morfologia original ou semipreservada correspondem àquelas que ainda não sofreram modificações significativas em termos de formas, materiais e processos. Referem-se a áreas dotadas de cobertura vegetal como parques urbanos, ou ainda, chácaras de lazer ou com atividades hortifrutigranjeiras. Embora possam ter sido alvo de intervenções antrópicas, não apresentam morfologias antropogênicas decorrentes diretamente da urbanização. As áreas de chácaras e reflorestamentos, por exemplo, embora já não tenham a cobertura vegetal original, não apresentam grandes porções de solo exposto ou impermeabilizado. Assim, ainda que a hidrodinâmica e a morfodinâmica dessas áreas possam ter sofrido mudanças, considerou-se que nessas áreas, por terem cobertura vegetal, a infiltração pode ser favorecida.

\section{Figura 6}

Mapa da morfologia antropogênica da bacia hidrográfica do rio Tamanduateí

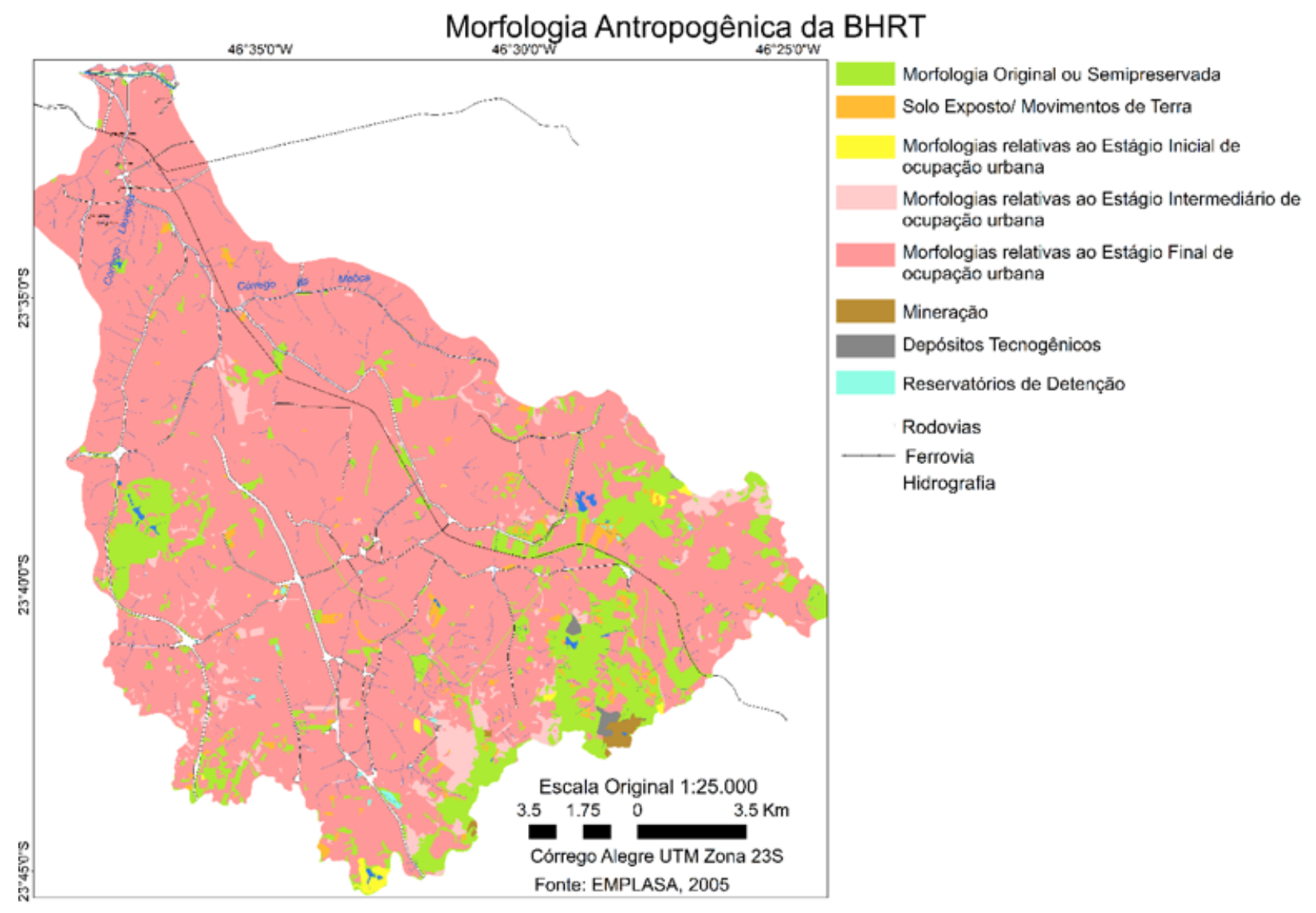


Considerou-se como morfologia antropogênica referente ao "estágio inicial de ocupação urbana" as áreas que correspondem a loteamentos desocupados ou em processo de ocupação, pois, geralmente, se constituem em áreas desprovidas de cobertura vegetal e com arruamentos, onde o escoamento superficial contribui para elevadas taxas de produção de sedimentos. Considera-se que essa morfologia apresenta tendência ao escoamento superficial difuso, mas com a ocorrência de fluxos concentrados no sistema viário.

As áreas mapeadas como "estágio intermediário de ocupação urbana", no caso da bacia hidrográfica do rio Tamanduateí, correspondem às áreas de favelas que, embora bastante impermeabilizadas em função da alta densidade de habitações, na maioria das vezes não têm pavimentação de ruas e sistemas de microdrenagem. Assim, no solo exposto dos arruamentos, geralmente se verificam processos erosivos lineares que formam sulcos e ravinamentos sendo, portanto, também consideradas áreas fontes de sedimentos. Considera-se que essa morfologia apresenta maior tendência ao escoamento concentrado.

As "áreas em estágio final de ocupação urbana" correspondem às áreas urbanas consolidadas, altamente impermeabilizadas, geralmente dotadas de infraestruturas. Constituem-se na morfologia antropogênica predominante na bacia hidrográfica do rio Tamanduateí, ocupando aproximadamente $82,4 \%$ do total da área.

Além das morfologias antropogênicas diretamente relacionadas à modalidade de intervenção antrópica "urbanização", destacam-se ainda, outras morfologias antropogênicas presentes no subsistema das vertentes, tais como "áreas de solo exposto/ movimento de terra" e "mineração". Ou ainda, relacionadas ao subsistema fluvial, tais como "canais fluviais retificados' e "canais fluviais tamponados".

As "áreas de solo exposto/movimento de terra" podem referir-se a áreas destinadas a cultivos agrícolas, ou ainda áreas de reflorestamentos recém-desmatadas ou recémcultivadas. No entanto, podem tratar-se de áreas onde serão implantados loteamentos, áreas industriais ou comerciais constituindo futuramente, morfologia antropogênica do "estágio inicial de urbanização". Por outro lado, tais áreas podem vir a ser abandonadas, quer seja pela simples mudança da intenção inicial de uso ou ainda, por exemplo, em função de restrições ambientais. Nestes casos, a área pode voltar a ter cobertura vegetal. Independentemente dos futuros usos aos quais essas áreas serão destinadas, a retirada da cobertura vegetal ao induzir o aumento do escoamento superficial, contribui para elevadas taxas de produção de sedimentos.

Embora a atividade de "mineração" seja considerada, por alguns autores, como sendo modalidade de intervenção antrópica distinta da urbanização, entendemos que, no caso da RMSP, apresenta relação intrínseca pois toda a atividade minerária se destina a atender as demandas da construção civil (areia, brita e argila). A atividade de mineração é responsável por uma série de impactos ambientais decorrentes de modificações nas formas, materiais e processos pois implica na retirada da cobertura 
vegetal, na modificação de morfologias (decapeamento, construção de diques e barragens, terraplenagem, modificações na rede de drenagem, formação de lagoas e deposição de rejeitos). Com relação aos materiais, a atividade promove o revolvimento do solo, a desestruturação de seus horizontes e aumento da compactação. Como resultado, os processos hidrodinâmicos em superfície, subsuperfície e subterrâneos são modificados.

As classes de morfologias semipreservadas e antropogênicas identificadas apresentam a seguinte distribuição, conforme se observa na Figura 7 .

\section{Figura 7}

\section{Distribuição das morfologias semipreservadas e antropogênicas na BHRT}

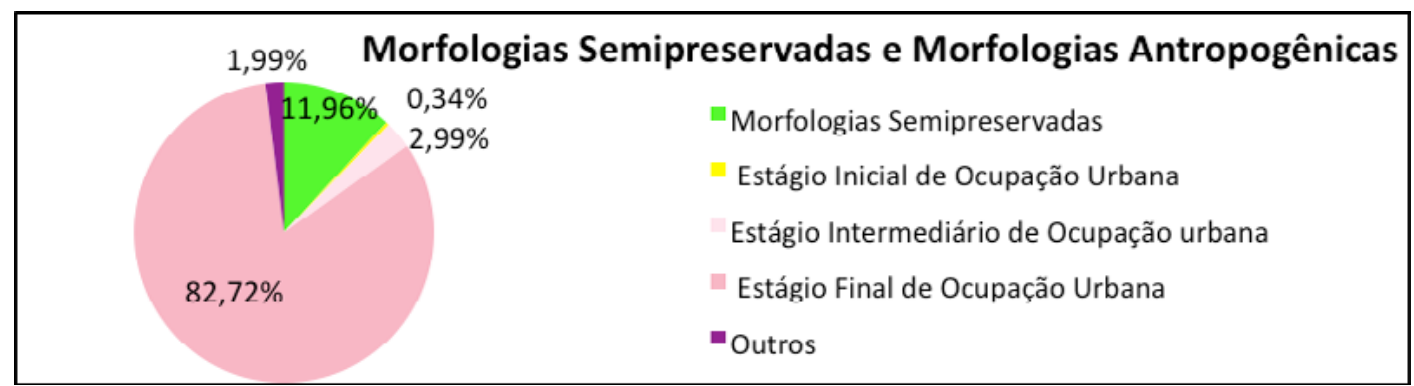

As morfologias antropogênicas relacionadas ao subsistema fluvial, tais como "canais fluviais retificados' e "canais fluviais tamponados" (Figura 8) apoiam-se no paradigma de "escoar a água o mais rápido possível". No município de São Paulo, e mais tarde na RMSP, a prática de canalizações encontrou respaldo na lógica de apropriação do espaço pela especulação imobiliária e na opção pelo transporte rodoviário urbano. Visando aumentar a velocidade dos fluxos dos cursos fluviais e, ao mesmo tempo, viabilizar a ocupação de várzeas e fundos de vale, foram implementadas técnicas para modificar as características hidráulicas das calhas fluviais. A prática de tais intervenções se processou de forma indiscriminada e desprovida de uma visão sistêmica que considerasse a totalidade da bacia hidrográfica. Cada projeto executado teve sua eficiência restrita à pequena área onde foi implantado e, por pequeno período de tempo; ao passo que o problema, transferido para as áreas adjacentes (à jusante), era amplificado pelo impacto gerado pelo próprio projeto executado à montante (Figura 9). Além disso, tais projetos não consideravam o uso e ocupação do solo e seus efeitos. Assim, ao serem executados, já se encontravam defasados em relação à realidade, não atendendo às vazões produzidas. Ressalta-se também que tais projetos eram, e muitas vezes ainda o são, elaborados a partir de modelos e simulações hidrológicas cujos parâmetros, desenvolvidos em outros países, não se aplicam à realidade do meio tropical úmido. Como resultado, o problema das inundações foi se agravando ainda mais. Enquanto nos países desenvolvidos esse princípio passou a ser abandonado ainda na década de 1970, nos países mais pobres, na mesma época, essa prática se tornou amplamente difundida (Moroz-Caccia Gouveia, 2016). 


\section{Figura 8}

Mapa das modificações nos canais fluviais da bacia hidrográfica do rio Tamanduateí

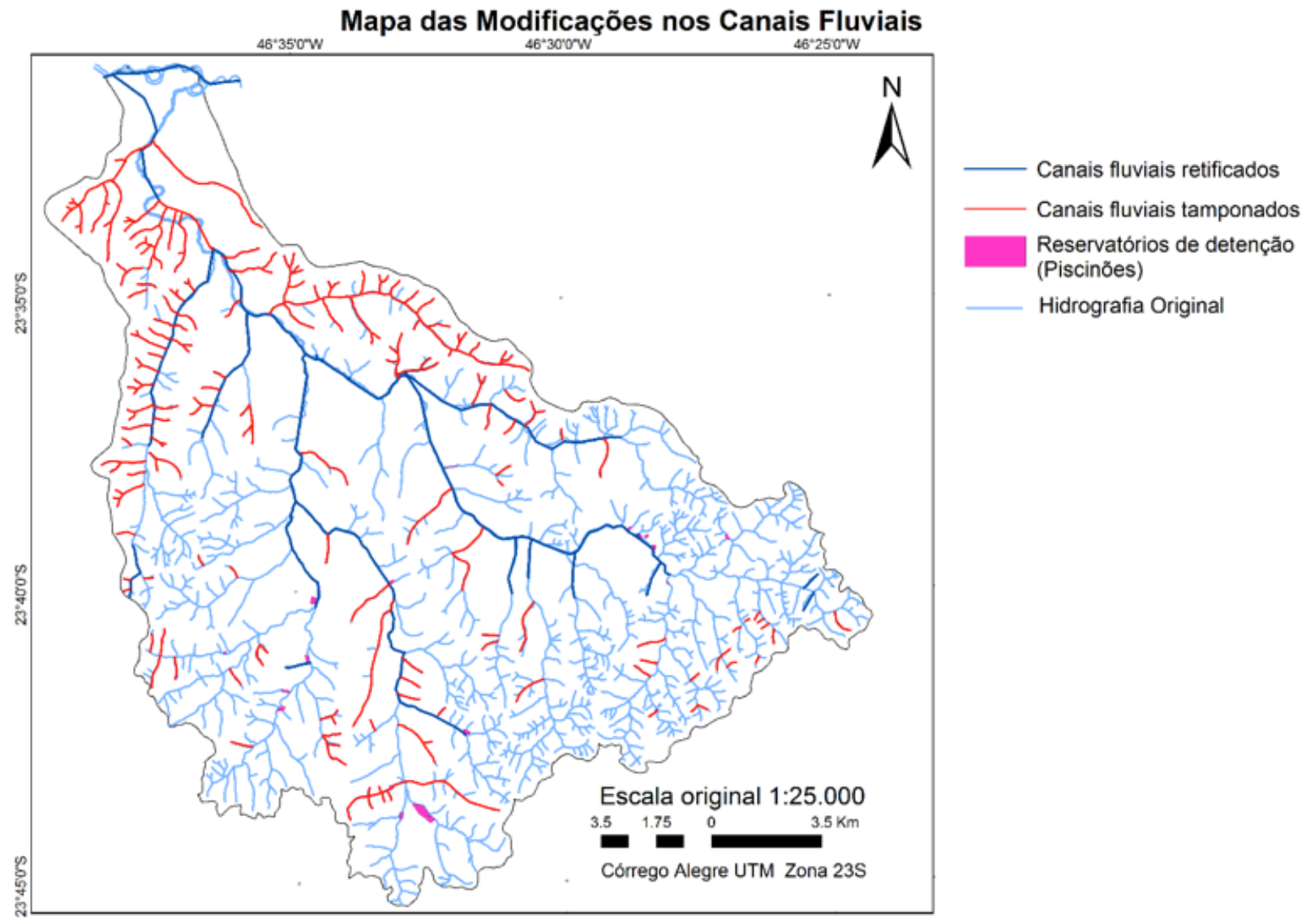

\section{Figura 9}

Diferenças no amortecimento do hidrograma de cheias em razão de modificações no traçado do canal fluvial

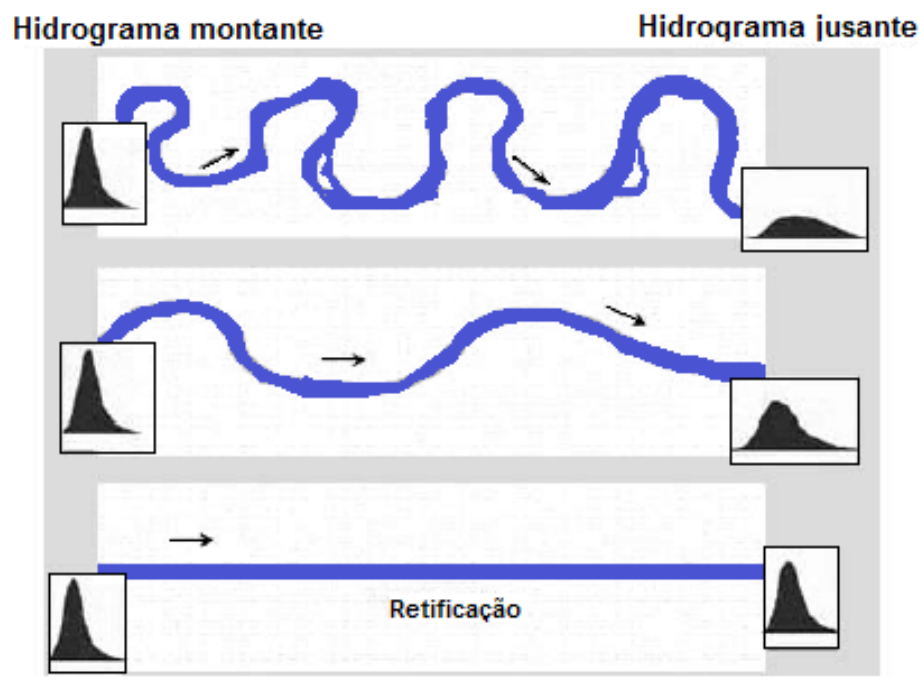

fonte: Rio de Janeiro (2001) 
A análise e correlação entre os produtos cartográficos elaborados permitem ainda avaliações espaciais quantitativas a partir de indicadores selecionados. Dentre as inúmeras possibilidades de leituras e interpretações, apresentam-se a seguir, de forma sintética, alguns resultados quantitativos das mudanças decorrentes da urbanização nos subsistemas físicos estudados.

Para o indicador hidromorfológico nos subsistemas conjuntos de vertentes, os valores obtidos para os parâmetros "áreas com tendência à infiltração" e "áreas com tendência ao escoamento superficial" (Quadro 3) refletem claramente os efeitos da ocupação urbana na bacia hidrográfica. Observa-se que o balanço hidrodinâmico foi modificado. Áreas com tendência à infiltração perderam essa funcionalidade, acentuando-se a tendência ao escoamento superficial.

\section{Quadro 3}

Valores do indicador hidromorfológico para os conjuntos de vertentes. Parâmetros "áreas com tendência à infiltração" e "áreas com tendência ao escoamento superficial"

\begin{tabular}{|c|c|c|c|c|}
\hline \multirow{2}{*}{ parâmetro } & \multirow{2}{*}{ unidade/elemento } & \multicolumn{2}{|c|}{ quadro } & magnitude da mudança \\
\cline { 3 - 4 } & & original & atual \\
\hline \multirow{2}{*}{$\begin{array}{c}\text { áreas com tendência à } \\
\text { infiltração }\end{array}$} & terrenos sedimentares & $50,7 \mathrm{~km}^{2}$ & $2,0 \mathrm{~km}^{2}$ & \multirow{2}{*}{ redução de $88,2 \%$} \\
\cline { 2 - 4 } & terrenos cristalinos & $29,0 \mathrm{~km}^{2}$ & $7,4 \mathrm{~km}^{2}$ & \multirow{2}{*}{ acréscimo de $29,7 \%$} \\
\hline \multirow{2}{*}{$\begin{array}{c}\text { áreas com tendência ao } \\
\text { escoamento superficial }\end{array}$} & terrenos sedimentares & $92,6 \mathrm{~km}^{2}$ & $141,4 \mathrm{~km}^{2}$ & \\
\cline { 2 - 4 } & terrenos cristalinos & $110,3 \mathrm{~km}^{2}$ & $121,8 \mathrm{~km}^{2}$ & \\
\hline
\end{tabular}

Essas modificações, além de acelerar os processos erosivos em áreas de solo exposto, implicam em menor tempo de permanência da água na bacia hidrográfica, o que acarreta na diminuição da recarga de lençol freático, interferindo na disponibilidade hídrica e acentuando variações sazonais. Induzem a ocorrência de enxurradas e o aumento de vazões de pico e, consequentemente, o aumento na frequência e magnitude de inundações.

Verificou-se também que as áreas com tendência ao escoamento superficial difuso foram substituídas por morfologias antropogênicas que favorecem o escoamento superficial concentrado (Quadro 4). 


\section{Quadro 4}

Valores do indicador hidrogeomorfológico para os conjuntos de vertentes. Parâmetros "áreas com tendência ao escoamento superficial difuso" e "áreas com tendência ao escoamento superficial concentrado"

\begin{tabular}{|c|c|c|c|c|}
\hline \multirow{2}{*}{ parâmetro } & \multirow{2}{*}{ unidade/elemento } & \multicolumn{2}{|c|}{ quadro } & \multirow{2}{*}{$\begin{array}{c}\text { magnitude da } \\
\text { mudança } \\
\%\end{array}$} \\
\hline & & original & atual & \\
\hline \multirow{2}{*}{$\begin{array}{l}\text { áreas com tendência ao } \\
\text { escoamento superficial difuso }\end{array}$} & terrenos sedimentares & $51,6 \mathrm{~km}^{2}$ & $23,3 \mathrm{~km}^{2}$ & \multirow{2}{*}{ redução de 65,8 \% } \\
\hline & terrenos cristalinos & $54,2 \mathrm{~km}^{2}$ & $12,8 \mathrm{~km}^{2}$ & \\
\hline \multirow{2}{*}{$\begin{array}{c}\text { áreas com tendência ao } \\
\text { escoamento superficial } \\
\text { concentrado }\end{array}$} & terrenos sedimentares & $41,1 \mathrm{~km}^{2}$ & $118,1 \mathrm{~km}^{2}$ & \multirow{2}{*}{ acréscimo de 161,5 \% } \\
\hline & terrenos cristalinos & $46,1 \mathrm{~km}^{2}$ & $109,1 \mathrm{~km}^{2}$ & \\
\hline
\end{tabular}

Para o subsistema planícies de inundação, o indicador materiais superficiais (Quadro 5) aponta que $39,9 \mathrm{~km}^{2}$ de áreas de planícies de inundação foram suprimidas por aterros e impermeabilizações, restando apenas $4.2 \mathrm{~km}^{2}$ com cobertura vegetal, preservando sua funcionalidade de armazenamento e de amortecimento de vazões de pico.

\section{Quadro 5}

Valores do indicador materiais superficiais e cobertura vegetal para planícies de inundação

\begin{tabular}{|c|c|c|c|c|}
\hline \multirow{2}{*}{ parâmetro } & \multicolumn{2}{|c|}{ quadro } & \multicolumn{2}{c|}{ magnitude da mudança } \\
\cline { 2 - 5 } & original & atual & área do total da \\
unidade & & redução de $39,9 \mathrm{~km}^{2}$ & redução de $90,5 \%$ \\
\hline cobertura vegetal & $\begin{array}{c}44,1 \mathrm{~km}^{2} \\
\text { (área total) }\end{array}$ & $4,2 \mathrm{~km}^{2}$ & aumento de $38,9 \mathrm{~km}^{2}$ & modificação em 88,2 \\
\hline solos perturbados & $0 \mathrm{~km}^{2}$ & $38,9 \mathrm{~km}^{2}$ & aumento de $1,0 \mathrm{~km}^{2}$ & modificação em $2,2 \%$ \\
\hline
\end{tabular}

Os valores obtidos nos subsistemas canais fluviais referentes ao indicador morfologia (parâmetros comprimento e padrão) explicitam o grau de artificialidade imposto pelas 
intervenções antrópicas (Quadros 6 e 7).

\section{Quadro 6}

Valores do indicador morfologia (parâmetros comprimento) para os canais fluviais

\begin{tabular}{|c|c|c|c|c|c|}
\hline \multirow{2}{*}{ parâmetro } & \multirow{2}{*}{ canal fluvial } & \multicolumn{2}{|c|}{ quadro } & \multicolumn{2}{c|}{ magnitude da mudança } \\
\cline { 3 - 6 } & original & atual & extensão & $\begin{array}{c}\text { \% do total } \\
\text { original }\end{array}$ \\
\hline \multirow{2}{*}{ comprimento } & rio Tamanduateí & $39,1 \mathrm{~km}$ & $36,3 \mathrm{~km}$ & redução de $2,8 \mathrm{~km}$ & redução de $7,1 \%$ \\
\cline { 2 - 5 } & $\begin{array}{c}\text { demais canais } \\
\text { fluviais }\end{array}$ & $662,5 \mathrm{~km}$ & $614,6 \mathrm{~km}$ & redução de $47,9 \mathrm{~km}$ & redução de $7,2 \%$ \\
\hline
\end{tabular}

\section{Quadro 7}

Valores do indicador morfologia (parâmetro padrão) para os canais fluviais

\begin{tabular}{|c|c|c|c|c|c|}
\hline \multirow{2}{*}{ parâmetro } & \multirow{2}{*}{ canal fluvial } & \multicolumn{3}{|c|}{ quadro } & \multirow{2}{*}{$\begin{array}{l}\text { magnitude da mudança } \\
\% \text { do total original }\end{array}$} \\
\hline & & original & ate & & \\
\hline \multirow{4}{*}{ padrão } & \multirow{2}{*}{ rio Tamanduateí } & \multirow{2}{*}{$39,1 \mathrm{~km}$} & retificado & $27,1 \mathrm{~km}$ & modificação em 69,3\% \\
\hline & & & tamponado & $2,5 \mathrm{~km}$ & modificação em 6,3\% \\
\hline & \multirow{2}{*}{ todos os canais fluviais } & \multirow{2}{*}{$701,6 \mathrm{~km}$} & retificados & $64,7 \mathrm{~km}$ & modificação em $9,2 \%$ \\
\hline & & & tamponados & $176,8 \mathrm{~km}$ & modificação em 25,2\% \\
\hline
\end{tabular}

Em relação ao comprimento dos canais, o rio Tamanduateí, que originalmente apresentava trechos meandrantes, sobretudo em seu baixo curso, sofreu retificação em $27,1 \mathrm{~km}$, o que corresponde a 69,3\% de sua extensão total, implicando em uma redução de $2,8 \mathrm{~km}$ em sua extensão. Os demais canais fluviais sofreram redução de 47,9 km de extensão, pois $9,2 \%$ do total sofreram retificações. Em relação aos tamponamentos, embora o rio Tamanduateí apresente apenas $2,5 \mathrm{~km}$ de seu curso confinado sob a Avenida do Estado, 176,8 km de cursos fluviais da bacia hidrográfica estão ocultos sob avenidas de fundos de vale. Ressalta-se que não foram consideradas, nessa pesquisa, as 
canalizações ${ }^{3}$ a céu aberto de cursos fluviais.

A Figura 10 apresenta as mudanças no comportamento hidrodinâmico da BHRT, decorrentes das modificações antrópicas.

\section{Figura 10}

Mudanças no comportamento hidrodinâmico da bacia hidrográfica do rio Tamanduateí. Porcentagens em relação à área total da bacia hidrográfica

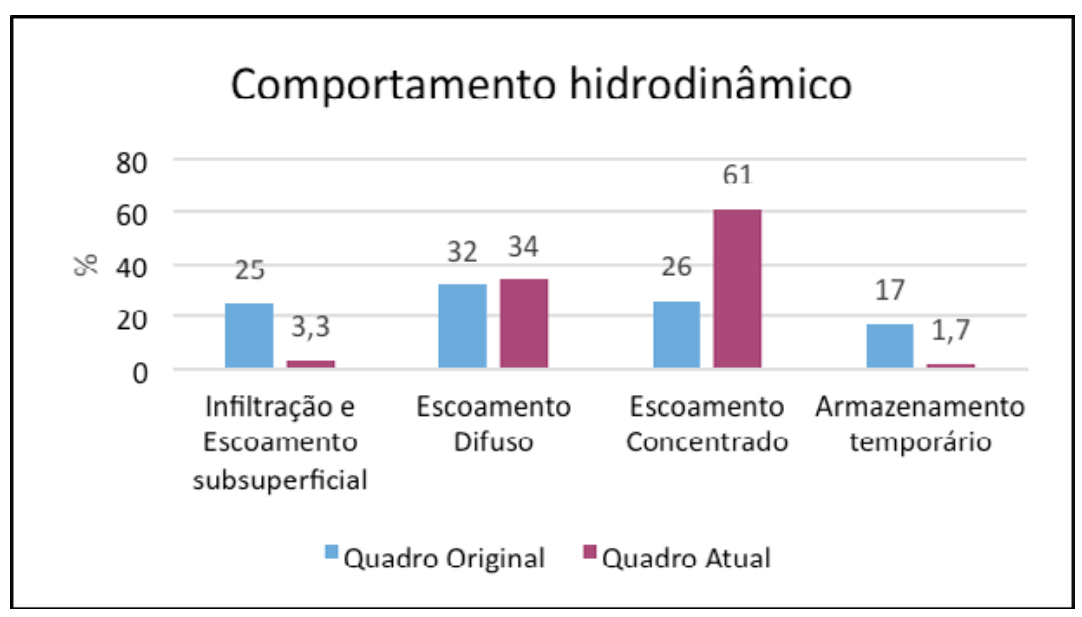

No quadro original, cerca de $25 \%$ das morfologias originais presentes na BHRT apresentavam tendência à infiltração. No quadro atual, essas morfologias foram reduzidas, equivalendo a cerca de 3,0\%. Nota-se que o quadro original da bacia hidrográfica apresentava um balanço bastante equilibrado entre as taxas de infiltração, escoamento superficial difuso e escoamento superficial concentrado. Ainda que, no gráfico, a tendência à infiltração se apresentasse inferior ao escoamento superficial no quadro original, deve-se ressaltar que tais raciocínios foram feitos levando-se em consideração principalmente a geometria e a setorização das morfologias originais das vertentes, sem levar em consideração, por exemplo, parâmetros físicos das formações superficiais e solos, além da cobertura vegetal. Acredita-se que, no quadro original, a diferença entre as taxas de infiltração e escoamento superficial fosse menos significativa. Já no quadro atual, verifica-se, pelas estimativas emárea, que a tendência ao escoamento superficial concentrado é muito maior que a tendência à infiltração e ao escoamento

3 Entende-se por canalização "toda obra ou serviço que tenha por objetivo dar forma geométrica definida para a seção transversal do curso d'água, ou trecho deste, com ou sem revestimento de qualquer espécie nas margens ou no fundo", de acordo com a definição apresentada no glossário de termos relacionados à gestão dos recursos hídricos (Igam, 2008). 
superficial difuso. Essas mudanças nos balanços de processos hidromorfodinâmicos podem explicar as mudanças na magnitude e frequência de inundações e na produção de sedimentos na bacia hidrográfica, lembrando que tais processos são ainda mais agravados pelo descarte inadequado de lixo e outros materiais tecnogênicos.

De acordo com Daee ([s.d]), na época do primeiro projeto de canalização na bacia hidrográfica, em 1890, a vazão de projeto era de $30 \mathrm{~m}^{3} / \mathrm{s}$ na foz do rio Tamanduateí. Simulações realizadas pelo CTH (Centro Tecnológico de Hidráulica-USP), ainda nos anos 1990, indicavam que, se a expansão da mancha urbana continuasse, com a bacia totalmente impermeabilizada, a vazão na foz poderia ultrapassar $800 \mathrm{~m}^{3} / \mathrm{s}$. Atualmente, admite-se que em alguns eventos a vazão pode chegar a $700 \mathrm{~m}^{3} / \mathrm{s}$ (Travassos, 2008). Considerando esses dados, a vazão máxima extrema na foz do rio Tamanduateí aumentou mais de 23 vezes.

Pesquisas do Centro de Ciência do Sistema Terrestre do Instituto Nacional de Pesquisas Espaciais (CCST-Inpe) e do IAG-USP afirmam que nos últimos 80 anos, os temporais tornaram-se mais frequentes e as chuvas aumentaram $30 \%$ na RMSP (Pivetta, 2012). Segundo os pesquisadores, de forma geral, dois fatores principais podem estar relacionados à alteração no regime de chuvas na região metropolitana: as mudanças climáticas globais, um fenômeno de grande escala, e o efeito ilha de calor, de caráter localizado e típico das cidades. Portanto, apontam que o próprio processo de urbanização interfere no regime de entrada de chuvas nos sistemas fluviais.

No entanto, os resultados obtidos na presente pesquisa evidenciam que a influência da urbanização não se restringe aos processos atmosféricos. $\bigcirc$ aumento de $2.300 \%$ da vazão de projeto (vazão extrema) do rio Tamanduateí (Daee, [s.d.]) não pode ser explicado exclusivamente pelo aumento de 30\% nas precipitações na RMSP.

Esse acréscimo pode ser atribuído, em grande parte, à impermeabilização verificada na bacia hidrográfica (Figura 11), embora contribuam também para esse incremento, as inúmeras canalizações e retificações dos afluentes do rio Tamanduateí, bem como inputs ou entradas de água de outras bacias hidrográficas pelo sistema de abastecimento público. Entretanto, cumpre destacar também, como importante fator de aumento das vazões na foz do rio Tamanduateí, a supressão das planícies de inundação.

4 Vazão de projeto pode ser estimada com base em séries de vazões históricas ou por meio de séries de precipitação (chuvas) junto com modelos hidrológicos do tipo precipitação-vazão (Villela; Mattos, 1975). 


\section{Figura 11}

\section{Correlação entre vazão e ocupação urbana na bacia hidrográfica do rio Tamanduateí}

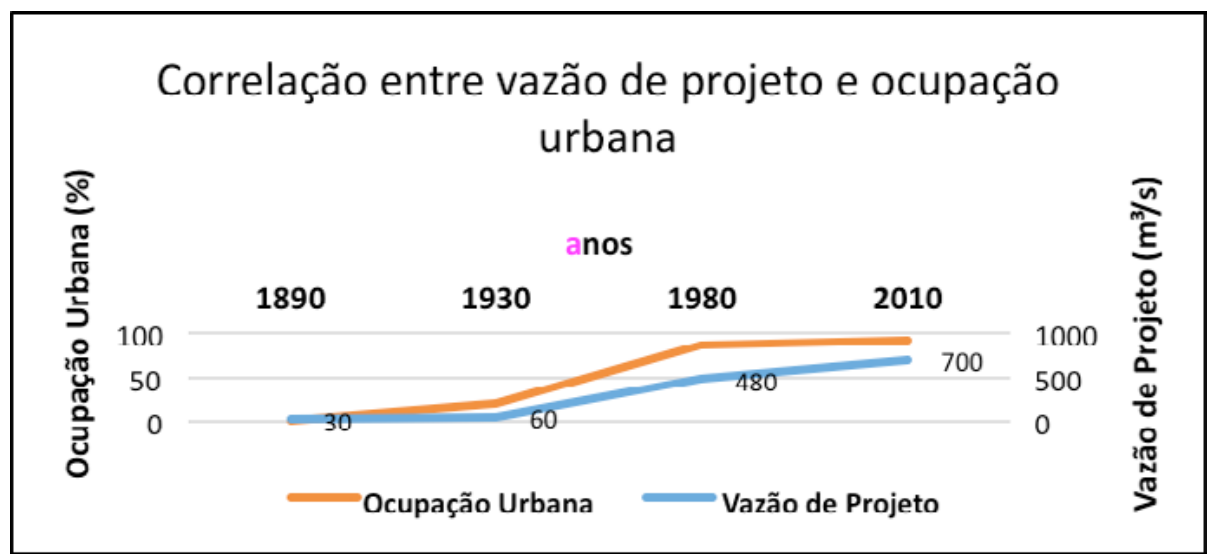

A avaliação quantitativa do indicador hidromorfológico (Quadro 8) sugere que as áreas de planícies de inundação na BHRT apresentavam, originalmente, capacidade de armazenar $44.100 .000 \mathrm{~m}^{3}$ de água nos eventos chuvosos. ${ }^{5}$ Atualmente, as poucas áreas de planície de inundação semipreservadas são capazes de armazenar apenas 4.200.000 $\mathrm{m}^{3}$ de água. Para suprir essa deficiencia, visando reduzir as vazões de pico na bacia hidrográfica e consequentemente no rio Tietê, optou-se pela construção de reservatórios de detenção ${ }^{6}$ (piscinões). Entretanto, apesar de todos os investimentos em obras estruturais para minimizar as inundações, os "piscinões" instalados e em funcionamento na bacia hidrográfica, ${ }^{7}$ representam apenas 7,9\% da capacidade de armazenamento das planícies de inundação anteriormente existentes. Essa condição seria para o caso de funcionamento pleno, sem o acúmulo de enormes cargas de sedimentos e lixo em seus interiores. Para reestabelecer a capacidade original de armazenamento oferecida pelas planícies de inundação, em um cenário original onde havia certo equilíbrio no balanço entre infiltração e escoamento superficial, seriam necessários cerca de 214 piscinões na bacia do rio Tamanduateí considerando-se, para efeito de cálculo, o volume médio do total de piscinões ali instalados e em funcionamento.

5 Para efeito de cálculo, se considerou que a capacidade natural de armazenamento das planícies de inundação é de $1 \mathrm{~m}^{3} / \mathrm{m}^{2}$ de superfície.

6 Reservatórios de detenção são reservatórios urbanos mantidos secos, enquanto os reservatórios de retenção têm uma lâmina de água e são utilizados não só para controlar o pico e o volume do escoamento, mas também a qualidade da água (Tucci, 2003).

7 Dos 46 reservatórios de detenção previstos para a bacia hidrográfica do rio Tamanduateí, 17 estavam implantados em 2010. O valor referente à capacidade máxima de armazenamento de águas dos reservatórios de detenção foi obtido na página eletrônica do Departamento de Águas e Energia Elétrica (Daee). 


\section{Quadro 8}

Valores do indicador processos hidromorfológicos para as planícies de inundação

\begin{tabular}{|c|c|c|c|}
\hline \multirow{2}{*}{ parâmetro } & \multicolumn{2}{|r|}{ quadro } & \multirow{2}{*}{$\begin{array}{l}\begin{array}{c}\text { magnitude da } \\
\text { mudança }\end{array} \\
\% \text { do total original }\end{array}$} \\
\hline & original & atual & \\
\hline \multirow{2}{*}{$\begin{array}{l}\text { áreas de } \\
\text { armazenamento } \\
\text { de águas }\end{array}$} & $\begin{array}{l}\text { planícies de } \\
\text { inundação } \\
44,1 \mathrm{~km}^{3} \\
\text { (capacidade de }\end{array}$ & $\begin{array}{c}\text { planícies de inundação } \\
4,2 \mathrm{~km}^{3} \\
\text { (capacidade de armazenamento de } \\
4.200 .000 \mathrm{~m}^{3} \text { ) }\end{array}$ & \multirow{2}{*}{$\begin{array}{c}\text { redução de } 82,6 \% \\
\text { da capacidade de } \\
\text { armazenamento de } \\
\text { águas }\end{array}$} \\
\hline & $\begin{array}{c}\text { armazenamento } \\
\text { de } 44.100 .000 \\
\left.\mathrm{~m}^{3}\right)\end{array}$ & $\begin{array}{c}\text { reservatório de detenção: } \\
0,43 \mathrm{~km}^{2} \text { (capacidade de armazenamento } \\
3.500 .000 \mathrm{~m}^{3} \text { ) }\end{array}$ & \\
\hline
\end{tabular}

\section{Considerações finais}

A RMSP e, principalmente, a cidade de São Paulo, vivenciam há décadas sérios transtornos causados por inundações e alagamentos nos períodos chuvosos. As inúmeras obras estruturais feitas na bacia hidrográfica do Alto Tietê, na tentativa de minimizar o problema, parecem ter efeitos efêmeros, pois ele persiste e alastra-se. No contexto metropolitano, ressalta-se que a BHRT contribui significativamente para os problemas de inundação, haja vista que "a grande restrição de funcionamento da calha do rio Tietê refere-se às contribuições de vazão do rio Tamanduateí que localmente dobram as vazões no rio Tietê, durante eventos hidrológicos significativos" (São Paulo, 1998).

Os dados obtidos nesta pesquisa mostram a magnitude das mudanças geomorfológicas, explicitando o impacto da urbanização em sistemas físicos. As informações geradas podem ser úteis para a gestão das águas em toda a RMSP, pois ajudam a identificar variáveis naturais e antrópicas e de agentes sociais responsáveis pelas mudanças identificadas. Em última análise, conduzem à reflexão sobre as estratégias até então adotadas para minimizar os problemas de inundação na bacia do Alto Tietê, identificando, por exemplo, os vultosos custos na construção de obras estruturais para restaurar algumas das funcionalidades hidromorfológicas perdidas.

\section{Referências}

AB'SÁBER, A. N. Natureza primária de São Paulo de Piratininga. Scientific American

Brasil, São Paulo, n. 25, jun. 2004a. Disponível em: http://www2.uol.com.br/sciam/ artigos/natureza primaria de sao paulo de piratininga imprimir.html. Acesso em: 3 abr. 2017.

São Paulo: ensaios entreveros. São Paulo: Edusp/Dosp, 2004b. 
- O Alto Tamanduateí e a região de Mauá: um roteiro de estudos para a elaboração de um projeto. In: SIMPÓSIO NASCENTES, 1., 2003, Mauá. Anais... Mauá: Prefeitura do Município de Mauá, 2003. p. 99-130.

. Mudanças urbanas em São Paulo. Publicações Sesc, São Paulo, n. 11, p. 33-34, 1999.

A planície do Tietê no Planalto paulistano. Geomorfologia, São Paulo, n. 57, p. 1-24, 1978.

O problema das paisagens originais do sítio urbano de São Paulo. Notícia Geomorfológica, Campinas, v. 4, n. 7-8, p. 52-55, 1961.

. O quaternário na bacia de São Paulo: estado atual dos conhecimentos. Geomorfologia, São Paulo, n. 8, p. 1-15, 1959.

Geomorfologia do sítio urbano de São Paulo. Tese (Doutorado em Geografia Física) - Faculdade de Filosofia, Ciências e Letras, Universidade de São Paulo, São Paulo, 1957.

. Os terraços fluviais da região de São Paulo. Anuário da Fac. De Filosofia do Instituto Sedes Sapientie, São Paulo, v. 10, p. 86-104, 1953.

BERGES, B. Geomorfologia urbana histórica aplicada à análise das inundações na bacia hidrográfica do Córrego da Moóca. Dissertação (Mestrado em Geografia Física) - Faculdade de Filosofia, Letras e Ciências Humanas, Universidade de São Paulo, São Paulo, 2013.

DAEE. DEPARTAMENTO DE ÁGUAS E ENERGIA ELÉTRICA. Rio Tamanduateí, [s.d.]. Disponível em: $\underline{w w w . d a e e . s p . g o v . b r}$. Acesso em: set. 2008.

. DePARTAMENTO de ÁGuAS E ENERGiA ElÉTRICA. Piscinões cumprem papel das várzeas ocupadas desordenadamente. São Paulo, [s.d]. Disponível em: $h$ ttp://www.daee.sp.gov.br/index.php?option $=$ com content $\mathcal{E} v i e w=$ article $\mathcal{E}$ id $=60$ :piscinoeshomeEcatid=38:piscinoesEItemid=13DAEE94. Acesso em: 13 mar. 2017.

DOUGLAS, I. The Urban environmental. Londres: Edward Arnold, 1983.

. The impact of urbanization on fluvial geomorphology in the humid tropics. In:

Symposium on Environmental Geomorphology in the Tropical Regions. Lubumbashi: Geo-Eco Trop, 1975. p. 229-242. Fasc.1-2. 
DYLIK, J. Notion du versant en geomorphologie. Bulletin de l'Academie Polonaise des Sciences, v. 16, n. 2, p. 125-132, 1968. Série des Sciences Geologiques et Geographiques.

EMPLASA. EMPRESA PAULISTA DE PLANEJAMENTO METROPOLITANO S.A; SEPLAN. A SECRETARIA MUNICIPAL DE PLANEJAMENTO E DESENVOLVIMENTO URBANO. Cartas de uso e ocupação do solo da RMSP e bacia hidrográfica do Alto Tietê. São Paulo: Emplasa/Fehidro, 2005. Escala 1:25.000.

GOUDIE, A. The human Impact in the Natural Environment. 4. ed. Cambridge: MIT Press, 1994.

The nature of the environment: an advanced physical geography. Oxford, UK: B. Blackwell, 1984.

GUPTA, A. The changing geomorphology of the humid tropics. Geomorphology, v. 7 , n. 1, p. 165-186, 1993.

IGAM. INSTITUTO MINEIRO de GESTÃO DAS ÁGUAS. Glossário de termos relacionados à gestão dos recursos hídricos. Belo Horizonte: IGAM, 2008. Disponível em: http://comites.igam.mg.gov.br/new/images/stories/Pdfl glossario\%2Bde\%2Brecursos\%2Bh\%EDdricos\%2B04\%5B1\%5D\%5B1\%5D.06.pdf. Acesso em: 19 maio 2010.

LAGO, P. C. Acervo do Museu Paulista da Universidade de São Paulo. Iconografia paulistana no século XIX. São Paulo: Metalivros, 1998.

LIMA, C. R. Urbanização e intervenções no meio físico na borda da bacia sedimentar de São Paulo: uma abordagem geomorfológica. Dissertação (Mestrado em Geografia Física) - Faculdade de Filosofia, Letras e Ciências Humanas, Universidade de São Paulo, São Paulo, 1990.

LUZ, R. A. Mudanças geomorfológicas na planície fluvial do rio Pinheiros, São Paulo-SP, ao longo do processo de urbanização. Tese (Doutorado em Geografia Física) - Faculdade de Filosofia, Letras e Ciências Humanas, Universidade de São Paulo, São Paulo, 2014.

MOROZ-CACCIA GOUVEIA, I. C. A cidade de São Paulo e seus rios: uma história repleta de paradoxos. Confins (Online), n. 27, 2016. Disponível em: http://confins. revues.org/10884. Acesso em: 17 mar. 2017. 
Da originalidade do sítio urbano de São Paulo às formas antrópicas: aplicação da abordagem da geomorfologia antropogênica na bacia hidrográfica do rio Tamanduateí, na Região Metropolitana de São Paulo. Tese (Doutorado em Geografia Física) - Faculdade de Filosofia, Letras e Ciências Humanas, Universidade de São Paulo, São Paulo, 2010.

NIR, D. Man, a geomorphological agent: an introduction to anthropic geomorphology. Jerusalém: Keter Publishing House, 1983.

PIVETTA, M. Da garoa à tempestade: temporais se tornam mais frequentes e chuva aumenta 30\% em São Paulo em 80 anos. Revista Pesquisa FAPESP, São Paulo, ed. 195, maio 2012.

RIO DE JANEIRO (Estado). Secretaria de Estado de Meio Ambiente e Desenvolvimento Sustentável. Revitalização de rios: orientação técnica. Rio de Janeiro: Semads, 2001. (Projeto Planagua Semads GTZ, de Cooperação Técnica Brasil/Alemanha).

RODRIGUES, C. Atributos ambientais no ordenamento territorial urbano: o exemplo das planícies fluviais na metrópole de São Paulo. Geousp - Espaço e Tempo (Online), v. 19, n. 2, p. 325-348, ago. 2015. ISSN 2179-0892. Disponível em: $<$ http:// www.revistas.usp.br/geousp/article/view/102805>. doi: http://dx.doi.org/10.11606/ issn.2179-0892.geousp.2015.102805.

Avaliação do impacto da urbanização em sistemas hidrogeomorfológicos: desenvolvimento e aplicação de metodologia na Grande São Paulo. Revista do Departamento de Geografia, São Paulo, n. 20, p. 111-125, 2010.

Avaliação do impactohumano da urbanização em sistemas hidrogeomorfológicos: desenvolvimento e aplicação de metodologia na Grande São Paulo. In: SIMPÓSIO NACIONAL DE GEOMORFOLOGIA, 7., 2008, Belo Horizonte. Anais... Belo Horizonte, 2008.

Sistemas geomorfológicos e o impacto da urbanização na Metrópole de São Paulo. SIMPÓSIO NACIONAL DE GEOMORFOLOGIA, 6., 2006, Goiânia. Guia de Excursão... Goiânia, 2006.

Morfologia original e morfologia antropogênica na definição de unidades espaciais de planejamento urbano: exemplo na metrópole paulista. Revista do Departamento de Geografia, São Paulo, n. 17, p. 101-111, 2005.

A urbanização da metrópole sob a perspectiva da geomorfologia: tributo a 
leituras geográficas. In: CARLOS, A. F. A.; OLIVEIRA, A. U. (Org.). Geografias de São Paulo: representações e crise da metrópole. São Paulo: Contexto, 2004. p. 89-114. v. 1.

Geomorfologia aplicada: avaliação de experiências e de instrumentos de planejamento físico-territorial e ambiental brasileiros. Tese (Doutoradoem Geografia Física) - Faculdade de Filosofia, Letras e Ciências Humanas, Universidade de São Paulo, São Paulo, 1997.

et al. Geomorfologia urbana histórica para avaliação de forçantes naturais e antrópicas na variabilidade da magnitude, frequência e das tendências espaciais de eventos de inundações em São Paulo. Meio ambiente e Geomática: Abordagens comparadas França-Brasil, Rennes, 12-15 nov. 2014. Disponível em: http:// envibras2014.sciencesconf.org. Acesso em: 17 abr. 2017.

; MOROZ-CACCIA GOUVEIA, I. C. Importância do fator antrópico na redefinição de processos geomorfológicos e riscos associados em áreas urbanizadas do meio tropical úmido: exemplos na Grande São Paulo. In: GUERRA, A. J. T.; JORGE, M. C. O. Processos erosivos e recuperação de áreas degradadas. São Paulo: Oficina de Textos, 2013. p. 66-94.

ROSS, J. L. S. Geomorfologia aplicada aos EIAs-RIMAs. In: GUERRA, A. J. T.; CUNHA, S. B. (Org.). Geomorfologia ambiental. Rio de Janeiro: Bertrand, 2004. p. 291336.

Geomorfologia, ambiente e planejamento. São Paulo: Contexto, 1990.

; MOROZ, I. C. Mapa geomorfológico do estado de São Paulo. São Paulo: Laboratório de Geomorfologia/DG-FFLCH-USP/IPT/Fapesp, 1997. v. I-II. Escala 1:500.000.

RUHE, R. V. Geomorphic processes and surficial geology. Geomorphology. Boston: Houghton Mifflin Company, 1975.

SÃO PAULO (Cidade). Secretaria Municipal de Cultura. Departamento de Patrimônio Histórico. Informativo do Arquivo Histórico Municipal Washington Luís. n. 4, set./out. 2008. Disponível em: http://www.arquiamigos.org.br/info/info20/index. html\#topo >. Acesso em: 6 dez. 2009.

SÃO PAULO (Estado). Plano Diretor de macrodrenagem da bacia hidrográfica do Alto Tietê. São Paulo: Consórcio Enger/Promon/CKC, 1998. 
SAVIGEAR, R. A. G. A technique of morphological mapping. Annals Association American Geographers, v. 55, n. 3, p. 514-538, 1965.

SCOTTISH EXECUTIVE ENVIRONMENT GROUP RESEARCH. Natural Flood Storage and Extreme Flood Events. Final Report. Edinburgh: JBA Consulting, 2005. p. 74.

SEABRA, O. C. Os meandros dos rios nos meandros do poder: Tietê e Pinheiros - valorização dos rios e das várzeas na cidade de São Paulo. Tese (Doutorado em Geografia Humana) - Faculdade de Filosofia, Letras e Ciências Humanas, Universidade de São Paulo, São Paulo, 1987.

TRAVASSOS, L. R. F. C. Macrodrenagem e expansão urbana na bacia do Alto Tietê. In: Tietê Vivo - Fórum de Difusão Científica para Inovações de Pesquisa e Extensão - 2007. São Paulo: USP, 2008. Disponível em: http://tietevivo.files. wordpress.com/2008/06/luciana-travessos.pdf. Acesso em: 15 fev. 2010.

TROEH, F. R. Landform equations fitted to contour maps. American Journal of Sciences, New Haven, v. 263, p. 616-627, 1965.

TUCCI, C. E. M. Drenagem urbana. Ciência e Cultura, São Paulo, v. 55 n. 4, p. 36-37, out./dez. 2003. Disponível em: http://cienciaecultura.bvs.br/scielo.php?script=sci arttextEpid=S0009-67252003000400020E-lng=ptEnrm=iso. Acesso em: 3 abr. 2010.

Aspectos institucionais do controle das inundações urbanas. In: TUCCI, C. E. M.; MARQUES, D. L. M. (Org.). Avaliação e controle da drenagem urbana. Porto Alegre: Editora da UFRGS, 2000. v. 1. Disponível em: http://www. iph.ufrgs. br/corpodocente/tucci/publicacoes/institu.PDF. Acesso em: 10 fev. 2010.

; COLLISCHONN, W. Drenagem urbana e controle de erosão. In: TUCCI, C. E. M.; MARQUES, D. L. M. (Org.). Avaliação e controle de drenagem urbana. Porto Alegre: Editora da UFRGS, 2000. p. 113-127. v. 1.

VILLELA, S. M.; MATTOS, A. Hidrologia aplicada. São Paulo: McGraw-Hill, 1975. 